\title{
Arsenic Contamination in Soils Affected by a Pyrite-mine Spill (Aznalcóllar, SW Spain)
}

\author{
J. Aguilar • C. Dorronsoro • E. Fernández • \\ J. Fernández • I. García • F. Martín • \\ M. Sierra • M. Simón
}

Received: 4 April 2006 / Accepted: 23 August 2006 / Published online: 4 November 2006

(C) Springer Science + Business Media B.V. 2006

\begin{abstract}
On 1998, a settling pond of a pyrite mine in Aznalcóllar (SW Spain) broke open, spilling some $3.6 \times 10^{6} \mathrm{~m}^{3}$ of water and $0.9 \times 10^{6} \mathrm{~m}^{3}$ of toxic tailings into the Agrio and Guadiamar river basin $40 \mathrm{~km}$ downstream, nearly to Doñana National Park. The soils throughout the basin were studied for arsenic pollution. Almost all the arsenic penetrated the soils in the solid phase (tailings) in variable amounts, mainly as a result of the different soil structure. The chemical oxidation of the tailings was the main cause of the pollution in these soils. A study of the relationships between the main soil characteristics and arsenic extracted with different reagents (water, $\mathrm{CaCl}_{2}$, acetic acid, oxalic-oxalate and EDTA) indicates a direct relationship with the total arsenic concentration. The highest amount of arsenic was extracted by oxalic-oxalate $(24 \%-36 \%$ of the total arsenic), indicating the binding with the iron oxides.
\end{abstract}

J. Aguilar $\cdot$ C. Dorronsoro $\cdot$ E. Fernández $\cdot$ J. Fernández $\cdot$

F. Martín $(\bowtie) \cdot$ M. Sierra

Soil Science Department, Faculty of Sciences,

University of Granada, Campus Fuentenueva s/n, 18002 Granada, Spain

e-mail: fjmartin@ugr.es

I. García $\cdot$ M. Simón

Soil Science Department, CITE IIB,

University of Almería, Ctra. Sacramento s/n,

04120 Almería, Spain
Keywords arsenic $\cdot$ fractionation $\cdot$ soil pollution

\section{Introduction}

Many studies on arsenic chemistry in contaminated soils indicate that arsenic can accumulate because it is only partially removed by leaching, methylation, and erosion or because it is slightly taken up and accumulated by plants. Different forms of arsenic identified in soils can be divided into two main groups: organic and inorganic compounds. Inorganic compounds are the most frequent in soil due to their water solubility.

Although information on the concentration and nature of arsenic in the soil solution under field conditions is scarce (Wenzel et al., 2001), many data are available on the nature and solubility of arsenic species under reducing conditions simulated in the laboratory. These studies show that $\mathrm{As}^{\mathrm{v}}$ species predominate in soil solutions under moderate reducing conditions, but $\mathrm{As}^{\mathrm{III}}$ forms are more abundant when the redox potential is below $500 \mathrm{mV}$ (Masscheleyn, Delaune, \& Patrick, 1991). These authors also indicate that a rise in $\mathrm{pH}$, or a fall in $\mathrm{As}^{\mathrm{v}}$ to $\mathrm{As}^{\mathrm{III}}$, boost the concentration of arsenic in the solution, while arsenic solubility under moderately reducing conditions is controlled by the dissolution of iron hydroxides (Marin, Masscheleyn, \& Patrick, 1993). On the other hand, it is well known that the arsenic concentration in a soil solution is governed by the physical and 
chemical properties of the soil, which influence adsorption-desorption processes. Arsenic has a high affinity for oxidic surfaces, and the reactivity of the oxides varies considerably with the $\mathrm{pH}$, the charge density and the composition of the soil solution. The soil texture and the nature of the mineral constituents also affect adsorption processes (Hiltbold, Hajek, \& Buchanan, 1974). Pierce and Moore (1980) demonstrated the specificity of the surface of iron hydroxides and the influence of $\mathrm{pH}$ in the arsenic adsorption.

In contrast to the abundant data on arsenic adsorption, little information is available on arsenic desorption in soils. In this sense, Carbonell, Burló, and Mataix (1996) discovered that the adsorption of As ${ }^{\mathrm{III}}$ forms is a reversible process, whereas the adsorption of $\mathrm{As}^{\mathrm{v}}$ is a hysteresial process.

Soils contaminated with arsenic are an immediate as well as a long-term hazard to the health of plants and animals, including humans (Smith, Naidu, \& Alston, 1998). The sources of arsenic in soils are different; according to the rock type, Bhumble and Keefer (1994), point out that sedimentary rocks contain proportionally more arsenic (between 1.7 and $40 \mathrm{mg} \mathrm{kg}^{-1}$ ) than do igneous rocks (between 1.5 and $3 \mathrm{mg} \mathrm{kg}^{-1}$ ). Reports have described arsenic contamination by agricultural activities or industrial origin as sulphuric acid and arsenic pesticide manufacturing (Aurilio, Durant, Hemond, \& Knox, 1995; Sadler, Olszowy, Shaw, Biltoft, \& Connell, 1994); also, mining activities are a major source of arsenic concentration in soils.

On 25 April 1998, a settling pond of a pyrite mine in Aznalcóllar (SW Spain) broke open (Figure 1), spilling some $3.6 \times 10^{6} \mathrm{~m}^{3}$ of water and $0.9 \times 10^{6} \mathrm{~m}^{3}$ of toxic tailings into the basins of the Agrio and Guadiamar rivers (Aguilar et al., 2003; Simón et al., 1998). The toxic tailings spread approximately $40 \mathrm{~km}$ downstream, reaching the wetlands of the Doñana National Park (proclaimed world heritage by UNESCO in 1994). The total affected area was roughly $55 \mathrm{~km}^{2} ; 2.9 \mathrm{~km}^{2}$ were river courses, $12.3 \mathrm{~km}^{2}$ eucalyptus forestation, $11.9 \mathrm{~km}^{2}$ cereals and olive trees, $9.9 \mathrm{~km}^{2}$ pastures, $5.4 \mathrm{~km}^{2}$ rice fields, $4.9 \mathrm{~km}^{2}$ marsh areas, $3.0 \mathrm{~km}^{2}$ orchards, $2.2 \mathrm{~km}^{2}$ cotton fields, $0.8 \mathrm{~km}^{2}$ riverbank vegetation, $0.8 \mathrm{~km}^{2}$ gravel beds, $0.5 \mathrm{~km}^{2}$ meadows, and $0.4 \mathrm{~km}^{2}$ vegetable crops (Aguilar, Dorronsoro, Galán, \& Gómez, 1999; Simón et al., 1999).

The present study examines the behaviour of arsenic in soils of different characteristics and the
Figure 1 Localization of the affected area and the seven sectors studied.

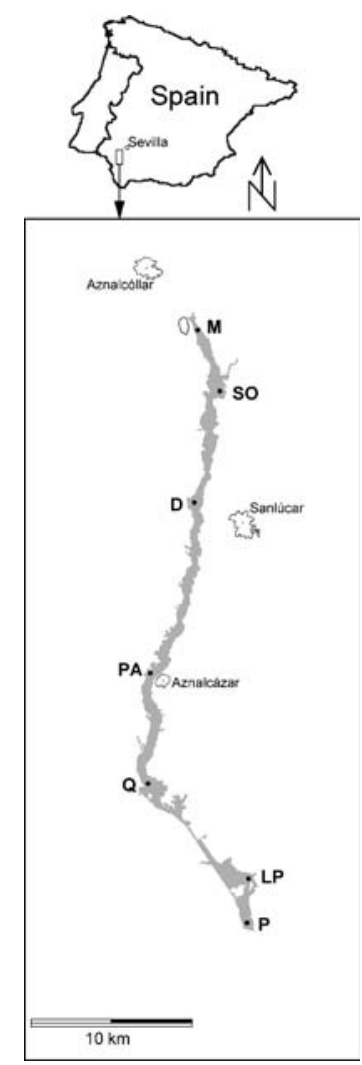

relationships between the different extraction reagents of arsenic and the soil properties.

\section{Materials and Methods}

Since this study has different objectives, the material used has also been varied. For the assessment of the initial pollution, seven sectors in the affected river basins were studied: near the Mine (M), Soberbina (SO), Puente de las Doblas (D), Aznalcázar (PA), Quema (Q), Los Pobres (LP) and Pescante (P) (Figure 1). These sectors were selected according to five parameters that key to the study of the Arsenic dynamics: $\mathrm{pH}, \mathrm{CaCO}_{3}$ content, texture, cation-exchange capacity, and iron oxide content (Figure 2).

As a means of establishing the arsenic contamination level in the basin, after the removal of the tailings covering the soils, a systematic sampling was made in the Guadiamar river basin, using a network (400× $400 \mathrm{~m}$ ) and selecting 91 sampling points. At each sampling point, samples were taken at the centre and 
Figure 2 Main soil properties of the sectors studied.

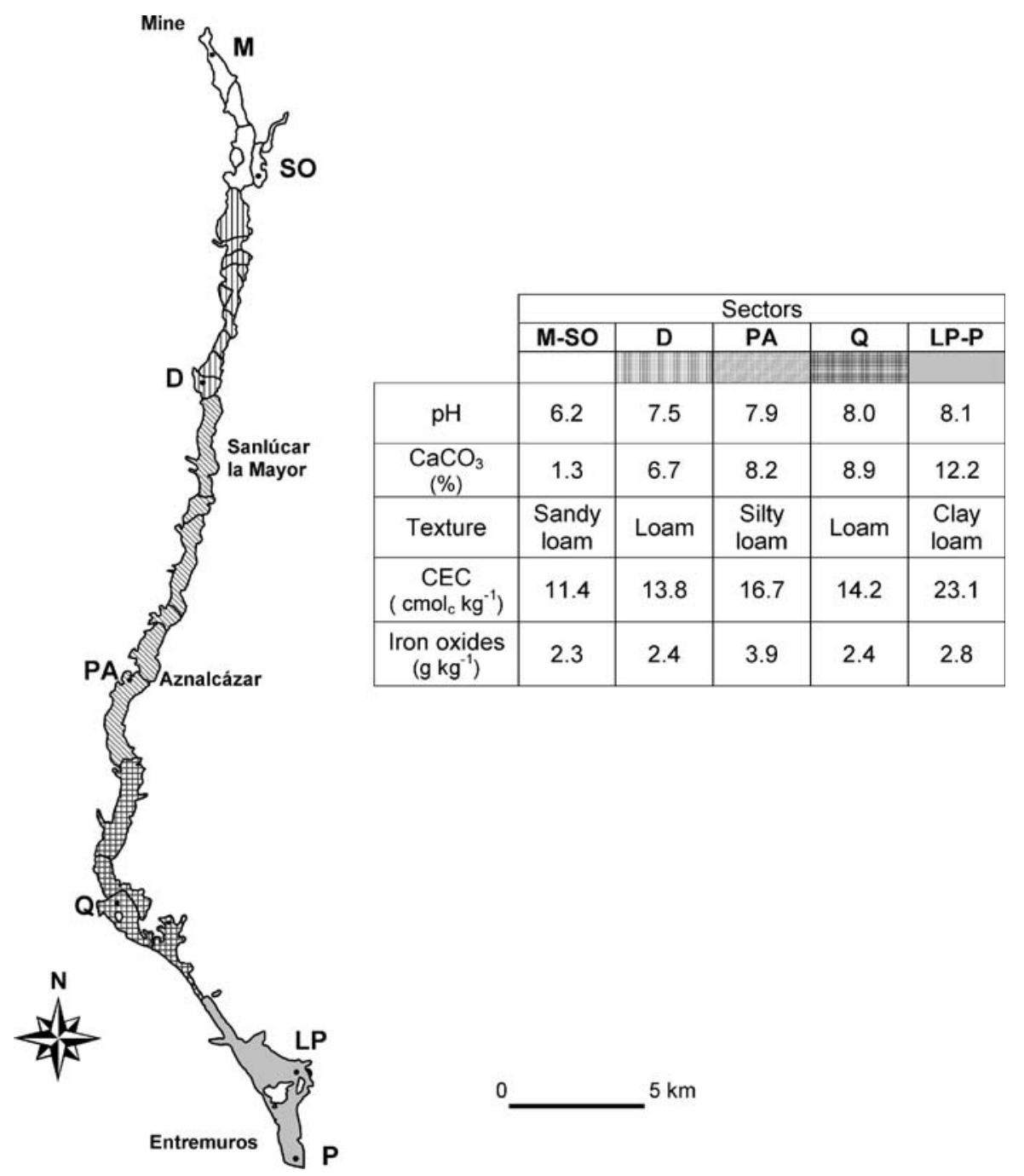

four corners of a square ( $10 \mathrm{~m}$ side), at $0-10,10-30$ and $30-50 \mathrm{~cm}$ in depth. The samples for the same depth were mixed and homogenized, finally obtaining three samples for each sampling point. Samples were also collected from uncontaminated soils in nearby areas unaffected by the spill.

In the study of the fractionation of arsenic forms and their relationships with the soil parameters that influence the immobilization processes, 91 sampling points were grouped in five different soil types according to the soil properties between 0 and 50 $\mathrm{cm}$ in depth, using a cluster analysis via the k-mean method, with significant differences $(P<0.05)$. Soil types 1 and 2, located in the upper part of the basin, were slightly acidic, with little or no carbonate; type 1 had a loamy texture while type 2 was dominated by sand and gravel. Soil types 3, 4 and 5 were predominantly neutral or slightly alkaline and with carbonate, the main differences between them being texture (type 3, clay loam; type 4, loam; type 5 , silty clay).

Finally, for monitoring the effect of the tailing oxidation in the soil, a plot with the tailings covering the soil was preserved for 465 days.

The contaminated and uncontaminated soils studied were classified as Typic Xerofluvent (upper part of the basin) and Typic Xerorthent (middle and lower part of the basin) (Soil Survey Staff, 2003). Field descriptions of soils were based on procedures of the Soil Survey Staff (1951).

Soil samples were air-dried and sieved to $2 \mathrm{~mm}$ to estimate the gravel content. Soil analyses were made with the $<2 \mathrm{~mm}$ fraction. Sulphate was determined in 
the saturation extract (water-soluble sulphate) by ion chromatography in a Dionex-120 chromatograph. Particle-size distribution was determined by the pipette method after elimination of organic matter with $\mathrm{H}_{2} \mathrm{O}_{2}$ and dispersion with sodium hexametaphosphate (Loveland \& Whalley, 1991). The $\mathrm{pH}$ was measured potentiometrically in a 1:2.5 soil:water suspension. The $\mathrm{CaCO}_{3}$ equivalent was determined by the method of Bascomb (1961). Total carbon was analysed by dry combustion with a LECO SC-144DR instrument. Organic carbon (OC) was determined by the difference between total carbon and inorganic carbon from $\mathrm{CaCO}_{3}$. The cation-exchange capacity (CEC) was determined with $1 \mathrm{~N}$ Na-acetate at $\mathrm{pH} 8.2$, measuring the sodium in a METEOR NAK-II flamephotometer. The total concentration of iron $\left(\mathrm{Fe}_{\mathrm{T}}\right)$ was measured by X-ray fluorescence in a Philips PW-1404 instrument, from a disc of soil and lithium tetraborate in a ratio of 0.6:5.5. Poorly crystallized iron oxides $\left(\mathrm{Fe}_{\mathrm{O}}\right)$ were extracted with ammonium oxalate (Schwertmann \& Taylor, 1977), and measured by atomic absorption spectroscopy.

Samples of the tailings and soils, finely ground $(<0.05 \mathrm{~mm})$, were digested in strong acids $\left(\mathrm{HNO}_{3}+\right.$ $\mathrm{HF}$ ) and the arsenic determined by ICP-MS in a Perkin Elmer Elan 5000 instrument. A Multi-element Calibration Standard 4 (Perkin-Elmer) was used with $\mathrm{Rh}$ as the internal standard. The detection limit for arsenic in soils measured by this technique was $0.01 \mu \mathrm{g}^{-1}$. The accuracy of the method was corroborated by analyses (six replicates) of a standard reference material: SRM 2711 (soil with moderately elevated trace-element concentrations; Gills \& Kane, 1993). For arsenic, the mean certified value was
$105.0 \mathrm{mg} \mathrm{kg}^{-1}$ with a standard deviation of 8.0 ; the mean experimental value was $102.4 \mathrm{mg} \mathrm{kg}^{-1}$ with a standard deviation of 1.1. For the fractionation of the arsenic forms, extractions were conducted with acetic acid $\left(\mathrm{As}_{\mathrm{A}}\right)$ (Ure, Quevauviller, Muntau, \& Griepink, 1993), calcium chloride $\left(\mathrm{As}_{\mathrm{C}}\right)$ (Novozamsky, Lexmond, \& Houba, 1993), EDTA (As EDTA $)$ (Quevauviller et al., 1998), ammonium oxalate ( $\left.\mathrm{As}_{\mathrm{O}}\right)$ (Schwertmann \& Taylor, 1977) and distilled water $\left(\mathrm{As}_{\mathrm{W}}\right)$ from a saturation extract of soil.

\section{Results and Discussion}

\subsection{Initial pollution}

Table I shows the results for the arsenic content in waters, tailings, and affected as well as unaffected soils nine days after the spill. It can be seen that the arsenic content in water decreased from the mine to the lower part of the basin (where the water stopped), whereas the arsenic content in tailings increased from the Mine to Pilas-Aznalcázar (middle part of the spill), and from there it decreased up to the limit where the tailing reached. The fact that some elements ( $\mathrm{Sn}, \mathrm{Bi}$ ) were no found in the contaminated water, indicated the amount of tailings that penetrated the soil, Simón et al. (1999) estimated that around 95\% of the arsenic concentration came from the direct input of tailings into the soil, while only $5 \%$ was due to the infiltration of polluted waters. In any case, the pollution was very heterogeneous, with values in affected soils similar to those of unaffected ones (close to $600 \mathrm{mg} \mathrm{kg}^{-1}$ ). This unevenness was owed in
Table I Arsenic content in waters, tailings and soils (contaminated (CS) and uncontaminated (UCS) by the spill), nine days after the spill

Max Maximum, Min minimum, $S D$ standard deviation

\begin{tabular}{lllll}
\hline Sector & $\begin{array}{l}\text { Water } \\
\left(\mu \mathrm{dm}^{-3}\right)\end{array}$ & $\begin{array}{l}\text { Tailings } \\
\left(\mathrm{mg} \mathrm{kg}^{-1}\right)\end{array}$ & $\mathrm{CS}(0-10 \mathrm{~cm})\left(\mathrm{mg} \mathrm{kg}^{-1}\right)$ & $\mathrm{UCS}(0-10 \mathrm{~cm})\left(\mathrm{mg} \mathrm{kg}^{-1}\right)$ \\
\hline M & 4.30 & $1,437.0$ & 29.0 & 17.5 \\
SO & 3.64 & $2,426.0$ & 20.1 & 15.8 \\
D & 3.16 & $3,884.0$ & 60.1 & 8.0 \\
PA & 2.66 & $4,122.6$ & 24.6 & 8.5 \\
Q & 2.14 & $3,834.2$ & 46.3 & 11.5 \\
P & 1.89 & $3,766.0$ & 598.2 & 26.0 \\
LP & 1.74 & $2,291.7$ & 73.8 & 11.2 \\
Max & 4.30 & $4,122.6$ & 598.2 & 26.0 \\
Min & 1.74 & $1,473.0$ & 20.1 & 8.0 \\
Mean & 2.79 & $3,113.5$ & 121.7 & 3.1 \\
SD & 1.34 & $1,066.4$ & 198.2 & 3.1 \\
\hline
\end{tabular}



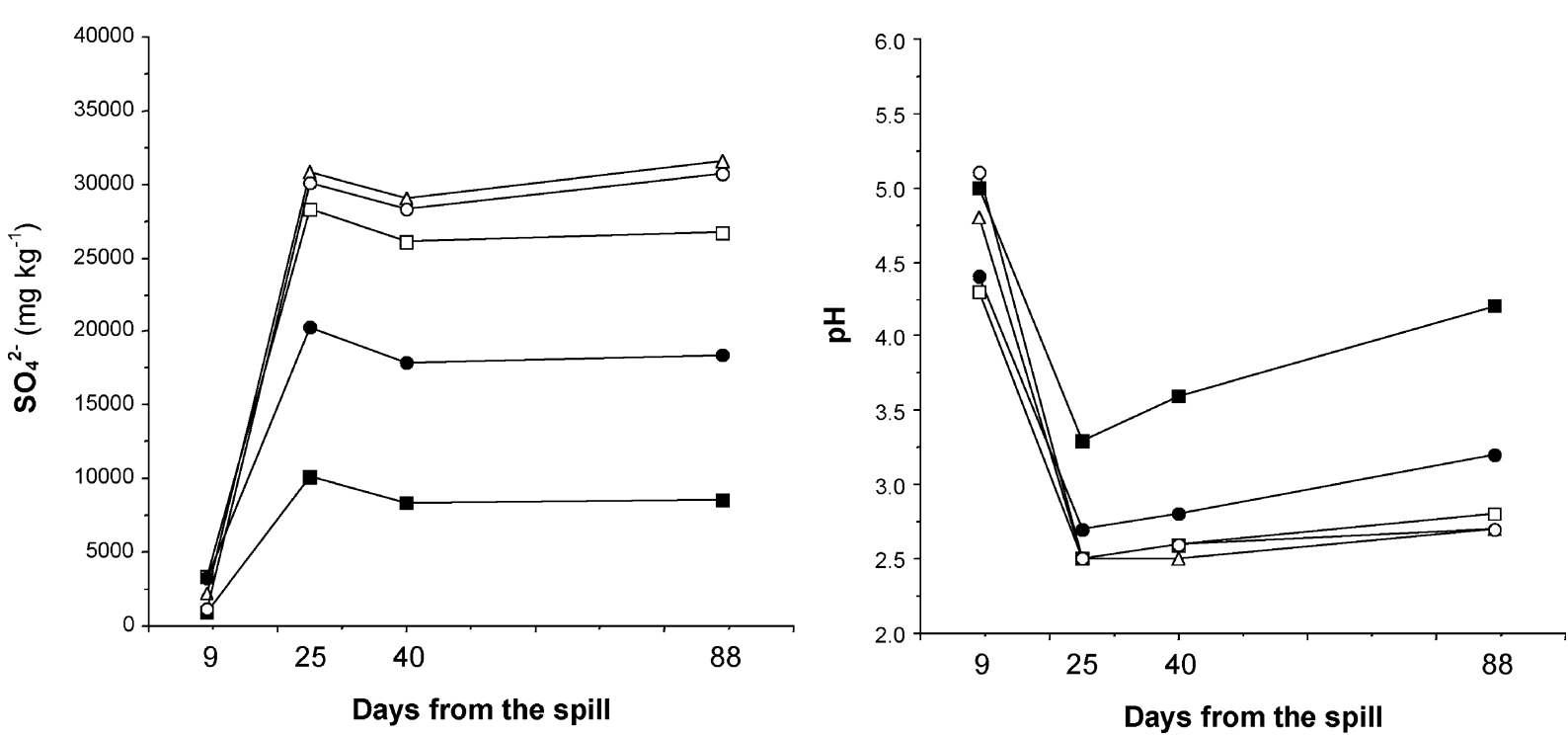

Figure 3 Variation in time of the sulphates and $\mathrm{pH}$ in the tailing solution (Sectors: $\bullet \mathrm{M}, \bullet \mathrm{SO}, \triangle \mathrm{PA}, \square \mathrm{Q}, \circ \mathrm{P}$ ).

part to soil properties, mainly structure, which affected the penetration of the tailings in the soil (Simón et al., 1999).

\subsection{Oxidative pollution}

In the pyrite tailings, as a result of drying and aeration, sulphides oxidize to sulphates (Nordstrom, 1982), the $\mathrm{pH}$ falls markedly due to the formation of sulphuric acid (Stumm \& Morgan, 1981) and the formerly insoluble pollutants partly solubilize.

During the days following the spill, this oxidation became evident, the sulphates increased rapidly in the

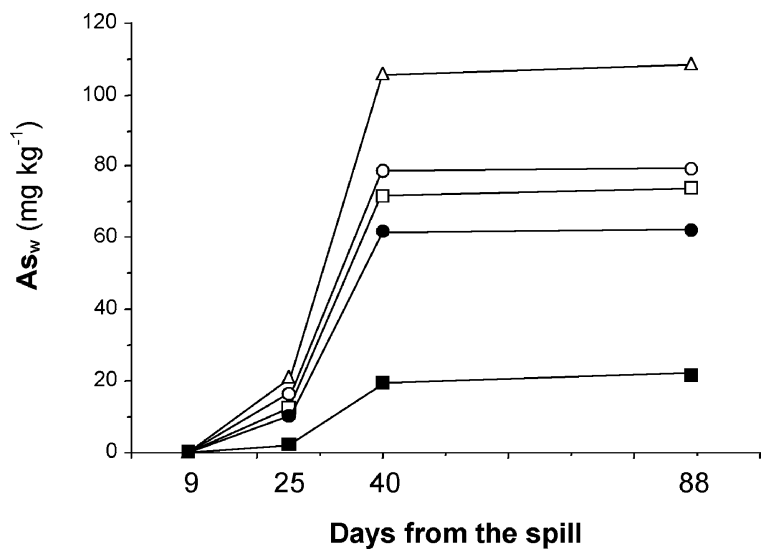

Figure 4 Variation in time of the water-soluble arsenic concentration in the tailings (Sectors: $-\mathrm{M}, \cdot \mathrm{SO}, \triangle \mathrm{PA}, \square \mathrm{Q}$, $\circ \mathrm{P})$. tailings solution, this being accompanied by a sharp fall in $\mathrm{pH}$ (Figure 3). The concentration of soluble arsenic, measured in a water extract of tailings, was also found to vary over time (Figure 4). Thus, although nine days after the spill no soluble arsenic was detected, values sharply increased over time. In this way, most of this solubilization occurred between 25 and 40 days from the spill (increasing more than fivefold the water-soluble arsenic in soil in relation to the previous period), when the oxidation

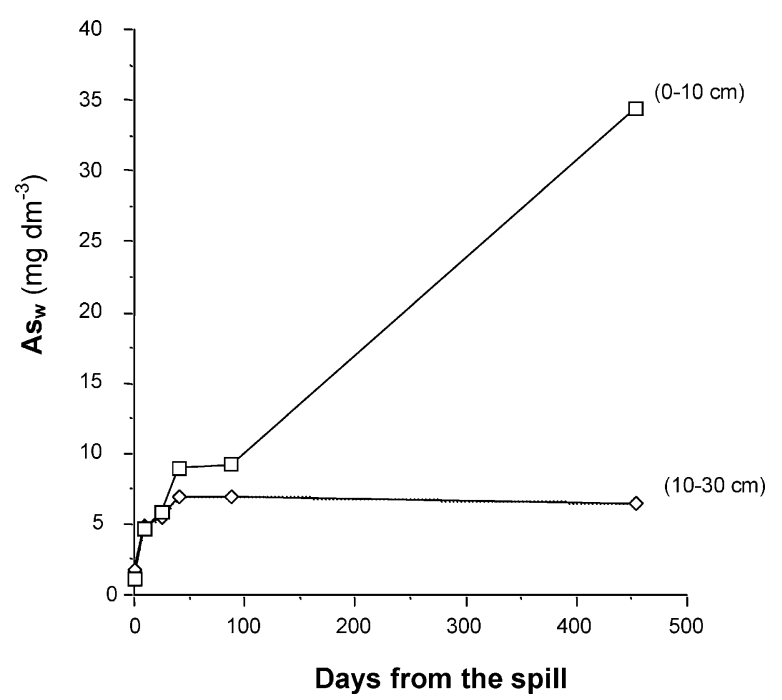

Figure 5 Variation in time of the water-soluble arsenic concentration (mean values of all sectors) in the soil at 0 $10 \mathrm{~cm}$ and $10-30 \mathrm{~cm}$ depth. 
and solubilization of the sulphides bonding to arsenic in the tailings were highest and a rainfall period occurred. At 88 days from the spill, the oxidative pollution was negligible. Figure 5 reflects the increase in water-soluble arsenic in the soils due to the oxidative pollution, and it can be seen that at 456 days after the spill, the arsenic concentration continued rising considerably over time in the surface samplings $(0-10 \mathrm{~cm})$ but without increasing the pollution in the samples at $10-30 \mathrm{~cm}$ in depth.

3.3 Arsenic content in the soils after the removal of the surface layer of tailings

The above results clearly demonstrated the need for immediate removal of the tailings and the upper layer of polluted soils, this being accomplished in four months. To test the effectiveness of the cleanup work after the removal of the tailings, the total arsenic content was determined, as well as arsenic extracted with distilled water $\left(\mathrm{As}_{\mathrm{W}}\right), \mathrm{CaCl}_{2}\left(\mathrm{As}_{\mathrm{C}}\right)$, acetic acid $\left(\mathrm{As}_{\mathrm{A}}\right)$, oxalic-oxalate $\left(\mathrm{As}_{\mathrm{O}}\right)$ and EDTA $\left(\mathrm{As}_{\mathrm{EDTA}}\right)$. Finally, we studied the relationship between the arsenic content and the soil properties that mainly influence its immobilization (iron oxides, clay, calcium carbonate, $\mathrm{pH}$ ).

\subsubsection{Total Arsenic Concentration}

Total arsenic, $\mathrm{S}$, iron $\left(\mathrm{Fe}_{\mathrm{T}}\right)$ and iron extracted with oxalic-oxalate $\left(\mathrm{Fe}_{\mathrm{O}}\right)$ in the five soil types, sampled at 91 points are shown in Table II. In the overall profile $(0-50 \mathrm{~cm})$, the soils with the highest concentrations in total arsenic were slightly acidic with a loamy texture (Type 1), their mean values approaching $100 \mathrm{mg} \mathrm{kg}^{-1}$, while those less affected were clayey soils at the end of the basin (Type 5), followed by the sandy carbonate (Type 4). In the uppermost $10 \mathrm{~cm}$ of the

Table II Mean values of total arsenic (As), total sulphur $(\mathrm{S})$, total iron $\left(\mathrm{Fe}_{\mathrm{T}}\right)$ and iron extracted with oxalic-oxalate $\left(\mathrm{Fe}_{\mathrm{O}}\right)$ in relation to the soil type and depth

\begin{tabular}{|c|c|c|c|c|c|c|c|c|c|c|c|c|c|}
\hline \multirow[t]{2}{*}{ Soil types } & \multirow[t]{2}{*}{ Depth $(\mathrm{cm})$} & \multicolumn{3}{|l|}{ As } & \multicolumn{3}{|l|}{$\mathrm{S}$} & \multicolumn{3}{|l|}{$\mathrm{Fe}_{\mathrm{T}}$} & \multicolumn{3}{|l|}{$\mathrm{Fe}_{\mathrm{O}}$} \\
\hline & & $\begin{array}{l}\text { Mean } \\
\left(\mathrm{mg} \mathrm{kg}^{-1}\right)\end{array}$ & $\mathrm{SD}$ & Sig & Mean (\%) & $\mathrm{SD}$ & Sig & Mean (\%) & $\mathrm{SD}$ & Sig & $\begin{array}{l}\text { Mean } \\
\left(\mathrm{g} \mathrm{kg}^{-1}\right)\end{array}$ & $\mathrm{SD}$ & Sig \\
\hline \multirow[t]{4}{*}{1} & $0-10$ & 256.38 & 237.95 & \multirow[t]{4}{*}{0.002} & 3.07 & 2.31 & \multirow[t]{4}{*}{0.001} & 8.93 & 2.93 & \multirow[t]{4}{*}{0.026} & 3.36 & 1.53 & \multirow[t]{4}{*}{0.013} \\
\hline & $10-30$ & 74.44 & 78.93 & & 1.00 & 1.26 & & 6.86 & 1.60 & & 2.03 & 1.33 & \\
\hline & $30-50$ & 43.39 & 29.88 & & 0.40 & 0.56 & & 6.86 & 0.70 & & 1.82 & 0.84 & \\
\hline & $0-50$ & 98.41 & 170.62 & & 1.47 & 1.90 & & 7.55 & 2.13 & & 2.40 & 1.40 & \\
\hline \multirow[t]{4}{*}{2} & $0-10$ & 180.74 & 187.87 & \multirow[t]{4}{*}{0.031} & 2.08 & 1.87 & \multirow[t]{4}{*}{0.018} & 9.11 & 4.81 & \multirow[t]{4}{*}{0.206} & 2.62 & 1.00 & \multirow[t]{4}{*}{0.028} \\
\hline & $10-30$ & 58.26 & 47.94 & & 0.82 & 0.52 & & 7.24 & 2.27 & & 1.90 & 0.71 & \\
\hline & $30-50$ & 58.77 & 63.47 & & 0.48 & 0.49 & & 6.41 & 1.70 & & 1.52 & 0.79 & \\
\hline & $0-50$ & 82.96 & 124.90 & & 1.16 & 1.35 & & 7.64 & 3.38 & & 2.03 & 0.94 & \\
\hline \multirow[t]{4}{*}{3} & $0-10$ & 209.46 & 292.36 & \multirow[t]{4}{*}{0.015} & 2.17 & 2.94 & \multirow[t]{4}{*}{0.005} & 6.88 & 3.06 & \multirow[t]{4}{*}{0.413} & 2.71 & 1.29 & \multirow[t]{4}{*}{0.187} \\
\hline & $10-30$ & 75.05 & 120.17 & & 0.58 & 0.93 & & 6.06 & 1.37 & & 2.07 & 1.48 & \\
\hline & $30-50$ & 52.15 & 31.08 & & 0.31 & 0.37 & & 6.18 & 1.01 & & 1.89 & 1.27 & \\
\hline & $0-50$ & 92.77 & 193.48 & & 0.98 & 1.89 & & 6.35 & 1.97 & & 2.21 & 1.38 & \\
\hline \multirow[t]{4}{*}{4} & $0-10$ & 90.12 & 90.72 & \multirow[t]{4}{*}{0.039} & 0.94 & 1.03 & \multirow[t]{4}{*}{0.002} & 5.85 & 2.15 & \multirow[t]{4}{*}{0.512} & 2.59 & 1.92 & \multirow[t]{4}{*}{0.672} \\
\hline & $10-30$ & 63.15 & 52.46 & & 0.41 & 0.37 & & 5.96 & 2.26 & & 2.74 & 2.13 & \\
\hline & $30-50$ & 45.51 & 36.03 & & 0.31 & 0.29 & & 5.32 & 1.91 & & 2.26 & 1.82 & \\
\hline & $0-50$ & 61.49 & 66.08 & & 0.56 & 0.71 & & 5.72 & 2.11 & & 2.53 & 1.95 & \\
\hline \multirow[t]{4}{*}{5} & $0-10$ & 114.86 & 208.05 & \multirow[t]{4}{*}{0.090} & 1.04 & 2.09 & \multirow[t]{4}{*}{0.128} & 6.91 & 1.96 & 0.540 & 2.04 & 0.96 & 0.526 \\
\hline & $10-30$ & 40.84 & 28.10 & & 0.21 & 0.21 & & 6.62 & 1.42 & & 2.16 & 1.21 & \\
\hline & $30-50$ & 29.58 & 17.38 & & 0.13 & 0.20 & & 6.23 & 0.94 & & 1.68 & 1.15 & \\
\hline & $0-50$ & 51.14 & 126.36 & & 0.46 & 1.26 & & 6.60 & 1.49 & & 1.97 & 1.10 & \\
\hline Mean & $0-10$ & 157.33 & 211.04 & $<0.001$ & 1.67 & 2.13 & $<0.001$ & 7.10 & 3.08 & $<0.001$ & 2.63 & 1.51 & 0.164 \\
\hline & $10-30$ & 63.43 & 73.85 & & 0.54 & 0.73 & & 6.36 & 1.87 & & 2.29 & 1.62 & \\
\hline & $30-50$ & 47.18 & 39.93 & & 0.32 & 0.38 & & 6.04 & 1.49 & & 1.92 & 1.36 & \\
\hline & $0-50$ & 75.71 & 139.44 & & 0.84 & 1.44 & & 6.50 & 2.29 & & 2.84 & 1.53 & \\
\hline
\end{tabular}

SD Standard deviation, Sig degree of significance in depths 
affected soils, the mean concentration was $157.3 \mathrm{mg}$ $\mathrm{kg}^{-1}$, with a maximum value of $1,226.8 \mathrm{mg} \mathrm{kg}^{-1}$.

The pollution exceeded the permitted value for agricultural soils (50 mg kg${ }^{-1}$ ) (Aguilar et al., 1999) in $82 \%$ of the overall surface area affected by the tailings, $96 \%$ in the acidic zone (soil types 1 and 2), and $76.8 \%$ in the carbonate zone (soil types 3, 4 and 5). Meanwhile, $53 \%$ of the affected soils surpassed the limit of $100 \mathrm{mg} \mathrm{kg}^{-1}$ maximum permitted for Natural Park in Andalusia (Aguilar et al., 1999). In all cases, the total arsenic decreased sharply in depth, without serious groundwater contamination (CSIC, 1998).

The analysis of bivariate correlations between the total arsenic $\left(\mathrm{As}_{\mathrm{T}}\right)$ and the properties of the uppermost $10 \mathrm{~cm}$ of the soils indicates that the arsenic was positively and significantly related to the total iron content $\left(\mathrm{Fe}_{\mathrm{T}}\right)$, amorphous iron oxides $\left(\mathrm{Fe}_{\mathrm{O}}\right)$, and sulphur. The correlation between the total arsenic and sulphur reveals a close relationship that can be quantified by the following equation:

$$
\begin{gathered}
\mathrm{As}_{\mathrm{T}}\left(\mathrm{mg} \mathrm{kg}^{-1}\right)=20.03+8.10 \mathrm{~S}\left(\mathrm{~g} \mathrm{~kg}^{-1}\right) \\
(P<0.05)
\end{gathered}
$$

\subsubsection{Arsenic Fractionation}

While the total arsenic values may be a valid reference for legislative reasons, they are not a reliable index for the mobility and bioavailability of arsenic in soils (Fedotov, Fitz, Wennrich, Morgenstern, \& Wenzel, 2005). Therefore, in Table III, we show soluble arsenic $\left(\mathrm{As}_{\mathrm{W}}\right)$ and values for arsenic extractable by $\mathrm{CaCl}_{2}\left(\mathrm{As}_{\mathrm{C}}\right)$, acetic acid $\left(\mathrm{As}_{\mathrm{A}}\right)$, oxalic-oxalate $\left(\mathrm{As}_{\mathrm{O}}\right)$ and EDTA $\left(\mathrm{As}_{\mathrm{EDTA}}\right)$, which indicate the potential pollution of this element.

In the overall profile (upper $50 \mathrm{~cm}$ of soil), the highest concentrations of $\mathrm{As}_{\mathrm{W}}$ were found in the carbonate soils (types 3 and 4), and those of $\mathrm{As}_{\mathrm{C}}$ in the carbonate soils with clayey texture (types 3 and 5 ). On the other hand, the slightly acidic soils (types 1 and 2) contained the highest concentrations of $\mathrm{As}_{\mathrm{EDTA}}$, due possibly to the dissolution from surfaces of iron oxides, whereas, in the case of $\mathrm{As}_{\mathrm{O}}$, the highest values were registered for slightly acidic soils with a loamy texture (type 1). However, $\mathrm{As}_{\mathrm{A}}$ showed no significant differences between soil types. When the soil $\mathrm{pH}<4.5$, the mean value of arsenic extracted with EDTA was fourfold greater than at higher $\mathrm{pH}$ values. Thus, strongly acidic $\mathrm{pH}$ values facilitate the

\begin{tabular}{|c|c|c|c|c|c|c|}
\hline Soil types & Depth (cm) & $\mathrm{As}_{\mathrm{W}}$ & $\mathrm{As}_{\mathrm{C}}$ & $\mathrm{As}_{\mathrm{A}}$ & $\mathrm{As}_{\mathrm{O}}$ & $\mathrm{As}_{\mathrm{EDTA}}$ \\
\hline \multirow[t]{4}{*}{1} & $0-10$ & 0.120 & 0.951 & 8.492 & 111.605 & 18.893 \\
\hline & $10-30$ & 0.036 & 0.771 & 3.411 & 26.123 & 2.890 \\
\hline & $30-50$ & 0.101 & 0.810 & 2.379 & 20.479 & 2.328 \\
\hline & $0-50$ & 0.079 & 0.823 & 4.014 & 40.962 & 5.866 \\
\hline \multirow[t]{4}{*}{2} & $0-10$ & 0.054 & 0.860 & 5.693 & 54.734 & 8.973 \\
\hline & $10-30$ & 0.042 & 0.813 & 2.394 & 22.604 & 5.164 \\
\hline & $30-50$ & 0.043 & 0.771 & 1.635 & 18.632 & 6.856 \\
\hline & $0-50$ & 0.045 & 0.806 & 2.750 & 27.441 & 6.603 \\
\hline \multirow[t]{4}{*}{3} & $0-10$ & 0.150 & 8.121 & 6.024 & 52.062 & 3.414 \\
\hline & $10-30$ & 0.082 & 1.044 & 3.238 & 19.275 & 2.346 \\
\hline & $30-50$ & 0.134 & 1.172 & 3.440 & 19.009 & 2.205 \\
\hline & $0-50$ & 0.116 & 2.511 & 3.876 & 25.726 & 2.503 \\
\hline \multirow[t]{4}{*}{4} & $0-10$ & 0.229 & 0.440 & 4.349 & 33.014 & 2.278 \\
\hline & $10-30$ & 0.163 & 0.498 & 2.809 & 21.185 & 2.309 \\
\hline & $30-50$ & 0.113 & 0.480 & 3.269 & 16.102 & 2.274 \\
\hline & $0-50$ & 0.156 & 0.479 & 3.301 & 21.518 & 2.289 \\
\hline \multirow[t]{4}{*}{5} & $0-10$ & 0.067 & 1.168 & 4.669 & 41.204 & 2.452 \\
\hline & $10-30$ & 0.073 & 1.127 & 3.954 & 18.722 & 1.988 \\
\hline & $30-50$ & 0.085 & 1.458 & 3.448 & 14.744 & 1.632 \\
\hline & $0-50$ & 0.077 & 1.268 & 3.895 & 21.627 & 1.938 \\
\hline
\end{tabular}

Table III Mean values $\left(\mathrm{mg} \mathrm{kg}^{-1}\right)$ of the different extracted forms of arsenic

$A s_{W}$ Water-soluble, $A s_{C}$ extracted with $\mathrm{CaCl}_{2}, A s_{A}$ with acetic acid, $A s_{O}$ with oxalic-oxalate, $A s_{E D T A}$ with EDTA 
mobilization of these arsenic forms. The buffering role of $\mathrm{CaCO}_{3}$ is clear, since the soils with content above $2.5 \%$ had threefold less arsenic extracted by EDTA than did soils with little or no carbonate content. In relation to the distribution in depth, the concentrations of $\mathrm{As}_{\mathrm{W}}$ and $\mathrm{As}_{\mathrm{C}}$ were quite uniform in all soil types, meanwhile the other forms $\left(\mathrm{As}_{\mathrm{A}}, \mathrm{As}_{\mathrm{O}}\right.$ and $\left.A s_{\text {EDTA }}\right)$ tended to concentrate in the surface.

We have also analysed the soil properties that could be involved in the mobility of the arsenic. The most important properties in connection with the possible mobilization or immobilization of arsenic are: $\mathrm{pH}, \mathrm{CaCO}_{3}$ content, fine-silt + clay content, or-
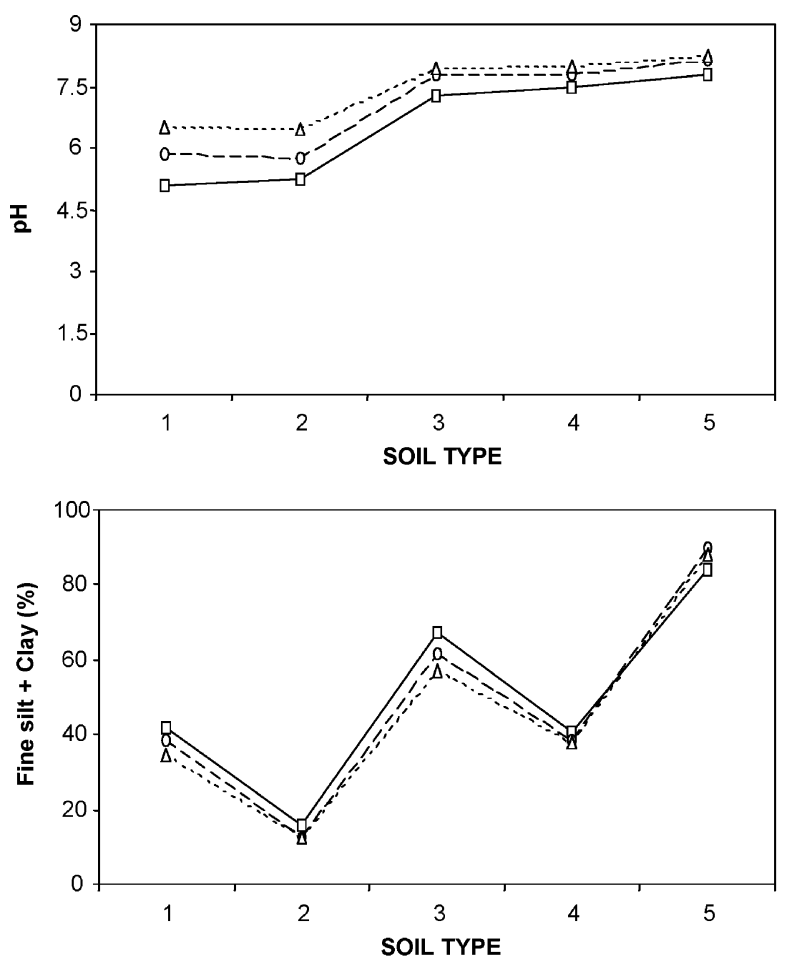

ganic carbon, and $\mathrm{Fe}_{\mathrm{O}}$ content (Hartley, Edwards, \& Lepp, 2004). Figure 6 indicates the average contents of each of the above properties in the five soil types considered and at the three depths studied $(0-10,10$ 30 and $30-50 \mathrm{~cm}$ ). This graph displays the rise in $\mathrm{pH}$ throughout the basin with the only exception of soil types 1 and 2 , because in the former the carbonate content is low and the texture is finer. On the other hand, the $\mathrm{pH}$ increases in all cases with the depth of the profile.

The carbonate content varies very little with depth and very markedly with the soil type, in relation to the parent material of the soil. Fine-silt + clay decreases
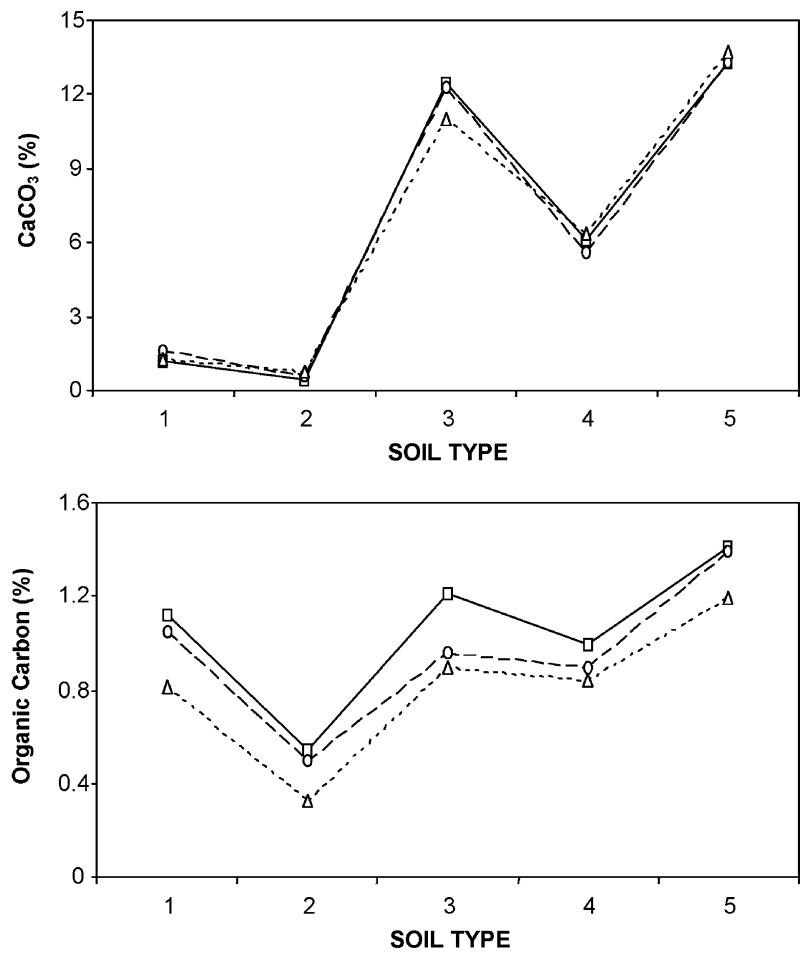

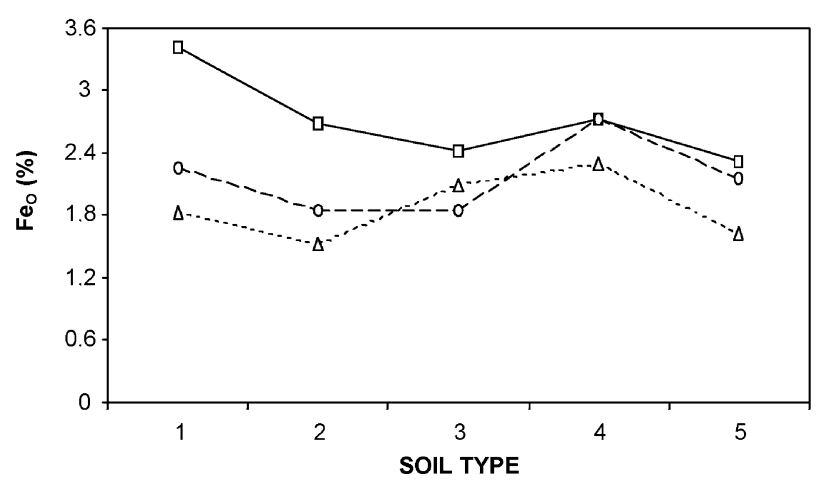

Figure 6 Main soil properties of the five soil types in depth $(\square 0-10 \mathrm{~cm}, \circ 10-30 \mathrm{~cm}, \triangle 30-50 \mathrm{~cm})$. 
with depth in the soil types 1, 2, 3 and 4, and increases in soil type 5 (common in marshland).

The OC content followed the same trend as finesilt + clay in the five soil types, naturally decreasing with the depth of the profile.

The $\mathrm{Fe}_{\mathrm{O}}$ had the highest contents near the mine, closely related to the amount of tailings deposited, part of which were not possible to remove and were mixed with the soil in the clean up activity.

The results from the principal-components analysis between the soil properties and the different extractions of arsenic (Table IV), indicate that around 75\% of the variance is explained by four components. The first relates the stronger extractants (acetic $\operatorname{acid}\left(\mathrm{As}_{\mathrm{A}}\right)$, ammonium oxalate $\left(\mathrm{As}_{\mathrm{O}}\right)$ and EDTA $\left.\left(\mathrm{As}_{\mathrm{EDTA}}\right)\right)$ with the total contamination, represented by the total arsenic $\left(\mathrm{As}_{\mathrm{T}}\right)$ and total sulphur $\left(\mathrm{S}_{\mathrm{T}}\right)$. The second component groups the main soil properties (calcium carbonate, fine silt and clay, organic carbon, and cation-exchange capacity). The third component indicates the inverse relationship between the iron extracted with ammonium oxalate $\left(\mathrm{Fe}_{\mathrm{O}}\right)$ and $\mathrm{pH}$; meanwhile, the last component relates the watersoluble arsenic $\left(\mathrm{As}_{\mathrm{W}}\right)$ and the arsenic extracted with calcium chloride $\left(\mathrm{As}_{\mathrm{C}}\right)$, also in an inverse way.

In this first statistical approach, we found a strong influence of the pollution on the different extracted

Table IV Principal-components analysis between the different extractions of arsenic and the main soil properties

\begin{tabular}{|c|c|c|c|c|}
\hline & \multicolumn{4}{|c|}{ Principal components } \\
\hline & Comp. 1 & Comp. 2 & Comp. 3 & Comp. 4 \\
\hline $\mathrm{As}_{\mathrm{W}}$ & & & & -0.776 \\
\hline $\mathrm{As}_{\mathrm{C}}$ & & & & 0.672 \\
\hline $\mathrm{As}_{\mathrm{A}}$ & 0.868 & & & \\
\hline $\mathrm{As}_{\mathrm{O}}$ & 0.942 & & & \\
\hline $\mathrm{As}_{\mathrm{EDTA}}$ & 0.645 & & & \\
\hline $\mathrm{As}_{\mathrm{T}}$ & 0.898 & & & \\
\hline $\mathrm{pH}$ & & & -0.585 & \\
\hline $\mathrm{CaCO}_{3}$ & & 0.622 & & \\
\hline F. silt + clay & & 0.905 & & \\
\hline $\mathrm{OC}$ & & 0.699 & & \\
\hline CEC & & 0.882 & & \\
\hline $\mathrm{Fe}_{\mathrm{O}}$ & & & 0.861 & \\
\hline $\mathrm{S}_{\mathrm{T}}$ & 0.908 & & & \\
\hline $\begin{array}{l}\text { Cumulative } \\
\text { variance }(\%)\end{array}$ & 31.1 & 51.9 & 64.4 & 75.1 \\
\hline
\end{tabular}

F. silt Fine silt, $O C$ organic carbon, $C E C$ cation-exchange capacity, $S_{T}$ total sulphur forms but could not identify any relationship between soil properties. Therefore, we performed several correlation and regression analyses grouping the samples according to the five soil types previously used.

3.3.2.1 Water-soluble arsenic $\left(A s_{W}\right)$ In the acidic soils (Types 1 and 2), the $\mathrm{As}_{\mathrm{W}}$ was related to the total concentrations of $\mathrm{As}_{\mathrm{T}}$, although the soluble concentrations were very low.

$$
\begin{gathered}
\mathrm{As}_{\mathrm{W}}\left(\mathrm{mg} \mathrm{kg}^{-1}\right)=0.00025 \mathrm{As}_{\mathrm{T}}\left(\mathrm{mg} \mathrm{kg}^{-1}\right) \\
(P<0.01)
\end{gathered}
$$

At the same time, given that the $\mathrm{As}_{\mathrm{T}}$ would be directly related to acidity (higher pollution, lower $\mathrm{pH}$ ), the $\mathrm{As}_{\mathrm{W}}$ was inversely and linearly related to $\mathrm{pH}$ :

$$
\mathrm{As}_{\mathrm{W}}\left(\mathrm{mg} \mathrm{kg}^{-1}\right)=0.24-0.03 \mathrm{pH} \quad(P<0.05)
$$

This reveals that for each unit of $\mathrm{pH}$ rising in these soils, the concentrations of soluble arsenic declined $0.03 \mathrm{mg}$. In this case, the critical concentration of $0.04 \mathrm{mg} \mathrm{kg}^{-1}$ of arsenic in soil solution (Bohn, McNeal, \& O'Connor, 1985) would be reached below $\mathrm{pH} 6.7$.

In the basic soils (Types 3, 4 and 5), the $\mathrm{As}_{\mathrm{W}}$ content was higher than in the acidic soils, and the relationship with $\mathrm{As}_{\mathrm{T}}$ can be expressed with the following equation:

$$
\begin{gathered}
\mathrm{As}_{\mathrm{w}}\left(\mathrm{mg} \mathrm{kg}^{-1}\right)=0.00078 \mathrm{As}_{\mathrm{T}}\left(\mathrm{mg} \mathrm{kg}^{-1}\right) \\
(P<0.001)
\end{gathered}
$$

This reflects that for each gram of total arsenic present in alkaline soils, almost $0.8 \mathrm{mg}$ was dissolved in water, around threefold more than in acidic soils.

The relationship with $\mathrm{pH}$ in these alkaline soils also differed from that of acidic ones, as $\mathrm{As}_{\mathrm{W}}$ decreased some $0.3 \mathrm{mg}$ per unit of increase in $\mathrm{pH}$ (10-fold more than in acidic soils).

$$
\mathrm{As}_{\mathrm{w}}\left(\mathrm{mg} \mathrm{kg}^{-1}\right)=2.39-0.30 \mathrm{pH} \quad(P<0.001)
$$

In this case, when the $\mathrm{pH}$ of alkaline soils reached 7.8 , the concentration of total arsenic would be enough to reach the critical arsenic concentration $\left(0.04 \mathrm{mg} \mathrm{kg}^{-1}\right)$ in soil solution. 
3.3.2.2 Arsenic extractable with $\mathrm{CaCl}_{2}\left(\mathrm{As}_{\mathrm{C}}\right)$ In the acidic soils, as in the case of $\mathrm{As}_{\mathrm{W}}, \mathrm{As}_{\mathrm{C}}$ was directly related to $\mathrm{As}_{\mathrm{T}}$.

$$
\operatorname{As}_{\mathrm{C}}\left(\mathrm{mg} \mathrm{kg}^{-1}\right)=0.003 \mathrm{As}_{\mathrm{T}}\left(\mathrm{mg} \mathrm{kg}^{-1}\right)
$$

$$
(P<0.001)
$$

There was a significant relationship between $\mathrm{As}_{\mathbf{C}}$ and $A s_{W}$, indicating that roughly $8 \%$ of the $\mathrm{As}_{\mathrm{C}}$ was water soluble.

$$
\begin{gathered}
\operatorname{As}_{\mathrm{C}}\left(\mathrm{mg} \mathrm{kg}^{-1}\right)=12.723 \mathrm{As}_{\mathrm{W}}\left(\mathrm{mg} \mathrm{kg}^{-1}\right) \\
(P<0.01)
\end{gathered}
$$

The $\mathrm{As}_{\mathrm{C}}$ in the alkaline soils, as the $\mathrm{As}_{\mathrm{W}}$, was also higher than in the acidic soils. Thus, when $\mathrm{As}_{\mathrm{C}}$ is related to $\mathrm{As}_{\mathrm{T}}$, the following regression equation results:

$$
\operatorname{As}_{\mathrm{C}}\left(\mathrm{mg} \mathrm{kg}^{-1}\right)=0.034 \mathrm{As}_{\mathrm{T}}\left(\mathrm{mg} \mathrm{kg}^{-1}\right)
$$

$$
(P<0.001)
$$

This indicates that, for each $50 \mathrm{mg} \mathrm{kg}{ }^{-1}$ of $\mathrm{As}_{\mathrm{T}}$ present in the basic soils, $1.7 \mathrm{mg} \mathrm{kg}^{-1}$ were extracted with calcium chloride, roughly 11 -fold more than in the acidic soils. This confirms that in the alkaline soils the toxic levels of easily bioavailable arsenic were reached at a much lower $\mathrm{As}_{\mathrm{T}}$ concentration than in acidic soils.

In contrast to acidic soils, alkaline soils showed no significant relationship between the $\mathrm{As}_{\mathrm{C}}$ and $\mathrm{As}_{\mathrm{W}}$. In addition, there was no significant relationship between $\mathrm{As}_{\mathrm{C}}$ and the cation-exchange capacity (CEC) or related parameters (organic matter and clay) both in acidic soils as well as in alkaline ones.

\subsubsection{Arsenic extractable with acetic acid $\left(A s_{A}\right)$} This extraction had no relationship with any soil property, and was related only to the total pollution and therefore with the concentrations of $\mathrm{As}_{\mathrm{T}}$, significant differences appearing between the acidic and basic soils. The linear regression equations were:

$$
\begin{array}{lc}
\text { Acidic soils } \mathrm{As}_{\mathrm{A}}\left(\mathrm{mg} \mathrm{kg}^{-1}\right)=0.030 \mathrm{As}_{\mathrm{T}}\left(\mathrm{mg} \mathrm{kg}^{-1}\right) & (\mathrm{P}<0.001) \\
\text { Basic soils } \mathrm{As}_{\mathrm{A}}\left(\mathrm{mg} \mathrm{kg}^{-1}\right)=0.017 \mathrm{As}_{\mathrm{T}}\left(\mathrm{mg} \mathrm{kg}^{-1}\right) & (\mathrm{P}<0.001)
\end{array}
$$

This indicates that in the acidic soils the concentrations of arsenic extractable with acetic acid was around $3 \%$ of the total arsenic, while in the alkaline soils these concentrations were only $1.7 \%$.
3.3.2.4 Arsenic extractable with EDTA $\left(A s_{E D T A}\right)$ In all the soils, $A s_{E D T A}$ proved to be lineally related to $\mathrm{As}_{\mathrm{T}}$, with significant differences between acidic and alkaline soils, indicating that EDTA extracted almost sevenfold more arsenic in acidic than in basic soils.

Acidic soils As $\operatorname{AsDTA}_{\mathrm{E}}\left(\mathrm{mg} \mathrm{kg}^{-1}\right)=0.068 \mathrm{As}_{\mathrm{T}}\left(\mathrm{mg} \mathrm{kg}^{-1}\right) \quad(P<0.001)$ Basic soils As $\operatorname{AsDTA}_{\mathrm{E}}\left(\mathrm{mg} \mathrm{kg}^{-1}\right)=0.010 \mathrm{As}_{\mathrm{T}}\left(\mathrm{mg} \mathrm{kg}^{-1}\right) \quad(P<0.001)$

arsenic occurred with acetic acid, $\mathrm{As}_{\text {EDTA }}$ was unrelated to any other soil property.

3.3.2.5 Arsenic extractable with oxalic-oxalate $\left(A s_{O}\right)$ The arsenic extracted with oxalic-oxalate was related to $\mathrm{As}_{\mathrm{T}}$, with significant differences between acidic and alkaline soils. The linear regression equations were:

$$
\begin{aligned}
& \text { Acidic soils } \mathrm{As}_{\mathrm{O}}\left(\mathrm{mg} \mathrm{kg}^{-1}\right)=0.359 \mathrm{As}_{\mathrm{T}}\left(\mathrm{mg} \mathrm{kg}^{-1}\right) \quad(P<0.001) \\
& \text { Basic soils As } \mathrm{As}_{\mathrm{O}}\left(\mathrm{mg} \mathrm{kg}^{-1}\right)=0.235 \mathrm{As}_{\mathrm{T}}\left(\mathrm{mg} \mathrm{kg}^{-1}\right) \quad(P<0.001)
\end{aligned}
$$

This signifies that oxalic-oxalate extracted approximately 1.5 -fold more arsenic in acidic (36\%) than in alkaline soils (24\%) (far higher than those extracted by other reagent); so the formation of amorphous iron oxides is considered the most important process in the retention of arsenic in this type of soils.

The correlation matrix between arsenic extracted with oxalic-oxalate $\left(\mathrm{As}_{\mathrm{O}}\right)$ and the most important soil properties related to the retention of elements (clay, organic carbon (OC), cation exchange capacity (CEC), calcium carbonate, and amorphous iron oxi-hydroxides $\left(\mathrm{Fe}_{\mathrm{O}}\right)$, indicated no other significant $(P<0.01)$ correlation than the one with $\mathrm{Fe}_{\mathrm{O}}$. The differences between slightly acidic and basic soils were also significant, being the correlation coefficient of 0.863 and 0.667 respectively; indicating a better relation in the retention of arsenic by iron oxi-hydroxides in the slightly acidic soils than in the basic ones.

\section{Conclusions}

In the pollution of soils affected by the pyrite-mine spill in Aznalcóllar (SW Spain), the chemical oxidation of the tailings was the main reason of the pollution in these soils. The total arsenic concentration exceeded the value of $50 \mathrm{mg} \mathrm{kg}^{-1}$ in $82 \%$ of the affected area. The study of the relationships between the main soil properties and arsenic extracted with different reagents (water, $\mathrm{CaCl}_{2}$, 
acetic acid, oxalic-oxalate and EDTA) indicates a direct relationship to the total concentration of arsenic in all cases. The highest amount of arsenic was extracted by oxalic-oxalate $(24 \%-36 \%$ of the total arsenic), indicating the preferential retention by amorphous phases of iron oxi-hydroxides.

Acknowledgments This study has been made possible by the research contract no. 1437 of the Regional Environmental Department of the Andalusian Government. Also thanks to Mr. David Nesbitt for the English correction of the manuscript.

\section{References}

Aguilar, J., Bellver, R., Dorronsoro, C., Fernández, E., Fernández, J., García I., et al. (2003). Contaminación de suelos por el vertido tóxico de Aznalcóllar (p. 184). Sevilla, Spain: Junta de Andalucía, Consejería de Medio Ambiente.

Aguilar, J., Dorronsoro, C., Galán, E., \& Gómez, J. L. (1999). Criterios y estándares para declarar un suelo como contaminado en Andalucía. In Univ. Sevilla (Ed.), Investigación y Desarrollo Medioambiental en Andalucía (pp. 45-59). Spain: University of Sevilla.

Aurilio, A. C., Durant, J. C., Hemond, H. F., \& Knox, M. L. (1995). Sources and distribution of arsenic in the Aberjona watershed, eastern Massachusetts. Water, Air and Soil Pollution, 81(3-4), 265-282.

Bascomb, C. L. (1961). A calcimeter for routine use on soil samples. Chemical Industry, 45, 1826-1827.

Bhumble, D. K., \& Keefer, R. F. (1994). Arsenic mobilization and bioavailability in soils. In J. O. Nriagu (Ed.), Arsenic in the environment. Part 1: Cycling and characterization (pp. 51-82). New York: Wiley and Sons.

Bohn, H. L., McNeal, B. L., \& O'Connor, G. A. (1985). Soil chemistry. New York: Wiley Interscience, Wiley \& Sons.

Carbonell, A., Burló, F., \& Mataix, J. (1996). Kinetics of arsenite desorption in Spanish soils. Communications in Soil Science and Plant Analysis, 27, 3101-3117.

CSIC. (1998). Technical report no. 6: Sobre la contaminación de los suelos tras el vertido de Aznalcóllar y el grado de lixiviación de los mismos. Sevilla, Spain: Junta de Andalucía, Consejería de Medio Ambiente.

Fedotov, P. S., Fitz, W. J., Wennrich, R., Morgenstern, P., \& Wenzel, W. W. (2005). Fractionation of arsenic in soil and sludge samples: Continuous-flow extraction using rotating coiled columns versus batch sequential extraction. Analytica Chimica Acta, 538, 93-98.

Gills, T. E., \& Kane, J. S. (1993). Certificate of analysis. Standard reference material 2711. Gaithersburg, USA: National Institute of Standards and Technology.

Hartley, W., Edwards, R., \& Lepp, N. W. (2004). Arsenic and heavy metal mobility in iron oxide-amended contaminated soils as evaluated by short- and long-term leaching tests. Environmental Pollution, 131, 495-504.

Hiltbold, A., Hajek, B. F., \& Buchanan, G. A. (1974). Distribution of arsenic in soil profiles after leaching. Soil Science Society of America Proceedings, 38, 647-652.
Loveland, P. J., \& Whalley, W. R. (1991). Particle size analysis. In K. A. Smith \& C. E. Mullis (Eds.), Soil analysis: Physical methods (pp. 271-328). New York: Marcel Dekker.

Marin, A., Masscheleyn, P. J., \& Patrick, W. H. (1993). Soil redox-pH stability of arsenic speciation. Environmental Science \& Technology, 33, 773-781.

Masscheleyn, P. J., Delaune, R. D., \& Patrick, W. H. (1991). Effect of redox potential and $\mathrm{pH}$ on arsenic speciation and solubility in a contaminated soil. Environmental Science \& Technology, 25, 1414-1418.

Nordstrom, D. K. (1982). Aqueous pyrite oxidation and the consequent formation of secondary iron minerals. In J. A. Kitrick, D. S. Fanning, \& L. R. Hossner (Eds.), Acid sulfate weathering (pp. 37-56). Madison, WI, USA: Soil Science Society of America.

Novozamsky, I., Lexmond, T. H., \& Houba, V. J. (1993). A single extraction procedure of soil for evaluation of uptake of some heavy metals by plants. International Journal of Environmental Analytical Chemistry, 51, 47-58.

Pierce, N. L., \& Moore, C. B. (1980). Adsorption of arsenite and arsenate on amorphous iron hydroxide from dilute aqueous solutions. Environmental Science \& Technology, 14, 214-216.

Quevauviller, P. H., La Chica, M., Barahona, E., Gómez, A., Rauret, G., Ure, A., et al. (1998). Certified reference material for the quality control of EDTA and DPTA extractable trace metal contents in calcareous soils (CRM 6000), Fresenius' Journal of Analytical Chemistry, 360, 505-511.

Sadler, R., Olszowy, H., Shaw, G., Biltoft, R., \& Connell, D. (1994). Soil and water contamination by arsenic from a tannery waste. Water, Air and Soil Pollution, 78(1-2), 189-198.

Schwertmann, U., \& Taylor, R. M. (1977). Iron oxides. In J. B. Dixon \& S. B. Webb (Eds.), Minerals in soil environments (pp. 148-180). Madison, WI: Soil Science Society of America.

Simón, M., Ortiz, I., García, I., Fernández, E., Fernández, J., Dorronsoro, C., et al. (1998). El desastre ecológico de Doñana. Edafología, 5, 153-161.

Simón, M., Ortiz, I., García, I., Fernández, E., Fernández, J., Dorronsoro, C., et al. (1999). Pollution of soils by the toxic spill of a pyrite mine (Aznalcóllar, Spain). Science of Total Environment, 242(1-3), 105-115.

Smith, I. C., Naidu, R., \& Alston, A. M. (1998). Arsenic in the soil environment. A review. Advances in Agronomy, 64, 150-195.

Soil Survey Staff. (1951). Soil survey manual. Handbook 18. Washington DC: USDA.

Soil Survey Staff. (2003). Keys to soil taxonomy (9th ed.) (p. 332). Blacksburg, Virginia: Pocahontas.

Stumm, W., \& Morgan, J. J. (1981). Aquatic chemistry: An introduction emphasizing chemical equilibria in natural waters. New York: John Wiley and Sons.

Ure, A. M., Quevauviller, P. H., Muntau, H., \& Griepink, B. (1993). Speciation of heavy metal in soils and sediments. An account of the improvement and harmonisation of extraction techniques undertaken under the auspices of the BCR of the Commission of the European Communities. International Journal of Environmental Analytical Chemistry, $51,135-151$.

Wenzel, W. W., Kirchbaumer, N., Prohaska, T., Stingeder, G., Lombi, E., \& Adriano, D. C. (2001). Arsenic fractionation in soils using an improved sequential extraction procedure. Analytica Chimica Acta, 436, 309-323. 